\title{
Synergistic Effects of Ambient Temperature and Air Pollution on Health in Europe: Results from the PHASE Project
}

\author{
Antonis Analitis ${ }^{1}$, Francesca de' Donato ${ }^{2}$, Matteo Scortichini ${ }^{2}$ (1) , Timo Lanki ${ }^{3,4}$,

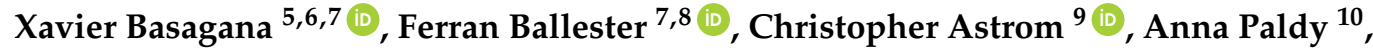 \\ Mathilde Pascal ${ }^{11}$, Antonio Gasparrini ${ }^{12,13}$, Paola Michelozzi ${ }^{2}$ and Klea Katsouyanni $1,14, *$ \\ 1 Department of Hygiene, Epidemiology, and Medical Statistics, Medical School, National and Kapodistrian \\ University of Athens, 11527 Athens, Greece; aanalit@med.uoa.gr \\ 2 Department of Epidemiology, Lazio Regional Health Service, 00147 Rome, Italy; \\ f.dedonato@deplazio.it (F.d.D.); m.scortichini@deplazio.it (M.S.); p.michelozzi@deplazio.it (P.M.) \\ 3 Department of Health Security, National Institute for Health and Welfare (THL), 70210 Kuopio, Finland; \\ timo.lanki@thl.fi \\ 4 Institute of Public Health and Clinical Nutrition, University of Eastern Finland, 70210 Kuopio, Finland \\ 5 Barcelona Institute for Global Health (ISGlobal), 08003 Barcelona, Spain; xavier.basagana@isglobal.org \\ 6 Department of Experimental and Health Sciences, Universitat Pompeu Fabra (UPF), 08002 Barcelona, Spain \\ 7 Spanish Consortium for Research on Epidemiology and Public Health (CIBERESP), 28029 Madrid, Spain; \\ ballester_fer@gva.es \\ 8 FISABIO, Epidemiology and Environmental Health Joint Research Unit, Universitat Jaume I, \\ Universitat de València, 46010 Valencia, Spain \\ 9 Unit of Occupational and Environmental Medicine, Department of Public Health and Clinical Medicine, \\ Umeå University, 90187 Umeå, Sweden; christofer.astrom@umu.se \\ 10 National Public Health Institute, Directorate of Public Health, 1097 Budapest, Hungary; \\ paldy.anna@oki.antsz.hu \\ 11 Department of Environmental Health (DSE), Santé Publique France, 94415 Saint Maurice, France; \\ m.pascal@invs.sante.fr \\ 12 Department of Public Health, Environments and Society, London School of Hygiene \& Tropical Medicine, \\ London WC1H 9SH, UK; Antonio.Gasparrini@lshtm.ac.uk \\ 13 Centre for Statistical Methodology, London School of Hygiene \& Tropical Medicine, London WC1E 7HT, UK \\ 14 Department of Population Health Sciences and Department of Analytical, Environmental and Forensic \\ Sciences, School of Population Health \& Environmental Sciences, King's College London, \\ London SE1 9NH, UK \\ * Correspondence: kkatsouy@med.uoa.gr; Tel.: +30-210-746-2086
}

Received: 22 June 2018; Accepted: 18 August 2018; Published: 28 August 2018

\begin{abstract}
We studied the potential synergy between air pollution and meteorology and their impact on mortality in nine European cities with data from 2004 to 2010. We used daily series of Apparent Temperature (AT), measurements of particulate matter $\left(\mathrm{PM}_{10}\right)$, ozone $\left(\mathrm{O}_{3}\right)$, and nitrogen dioxide $\left(\mathrm{NO}_{2}\right)$ and total non-accidental, cardiovascular, and respiratory deaths. We applied Poisson regression for city-specific analysis and random effects meta-analysis to combine city-specific results, separately for the warm and cold seasons. In the warm season, the percentage increase in all deaths from natural causes per ${ }^{\circ} \mathrm{C}$ increase in AT tended to be greater during high ozone days, although this was only significant for all ages when all causes were considered. On low ozone days, the increase in the total daily number of deaths was $1.84 \%$ (95\% CI $0.87,2.82)$, whilst it was $2.20 \%(95 \%$ CI $1.28,3.13)$ in the high ozone days per $1{ }^{\circ} \mathrm{C}$ increase in AT. Interaction with $\mathrm{PM}_{10}$ was significant for cardiovascular (CVD) causes of death for all ages (2.24\% on low $\mathrm{PM}_{10}$ days $(95 \% \mathrm{CI} 1.01,3.47)$ whilst it is $2.63 \%(95 \% \mathrm{CI} 1.57,3.71)$ on high $\mathrm{PM}_{10}$ days $)$ and for ages $75+$. In days with heat waves, no consistent pattern of interaction was observed. For the cold period, no evidence for synergy was
\end{abstract}


found. In conclusion, some evidence of interactive effects between hot temperature and the levels of ozone and $\mathrm{PM}_{10}$ was found, but no consistent synergy could be identified during the cold season.

Keywords: temperature; air pollution; climate change and extreme weather events; interaction; short-term health effect; vulnerability

\section{Introduction}

There has been an increasing awareness of the acute health effects of temperature extremes, particularly heat, supported by a growing body of scientific evidence [1-6]. Recent evidence on the effects of hot weather, such as the high mortality experienced during the extreme heat wave that struck Europe in the summer of 2003, has raised public concern [7,8].

Air pollution is also a well-known public health risk factor. In the past 25 years, results from many epidemiologic studies have given evidence for a positive association between air pollutants concentrations and total and cause-specific mortality [9-11]. Large multicity studies in Europe, USA, and other part of the world have documented and quantified the adverse effects of air pollution on health [12-14]. Fine particles ( $\left.\mathrm{PM}_{10}, \mathrm{PM}_{2.5}\right)$, ozone, nitrogen dioxide, and sulfur dioxide-even at relatively low concentrations-have been linked with increases in morbidity and mortality.

Air pollution concentrations are determined to an extent by prevailing meteorological conditions. For example, as $\mathrm{O}_{3}$ is formed by a photochemical reaction, the intensity of solar radiation during heat waves leads to a rise in $\mathrm{O}_{3}$ concentrations, whilst the decrease in rainfall may also enhance ambient pollutant concentrations. Climate change could affect air quality directly but also indirectly via changes in human behavior [15]. There is a lot of knowledge available on how current weather does affect air pollutant concentrations. Climate change can affect local to regional air quality directly through changes in chemical reaction rates, boundary layer heights that affect vertical mixing of pollutants, and changes in synoptic airflow patterns that govern pollutant transport. Energy demand could also increase, and as we continue to rely on the combustion of fossil fuels, this could lead to an increase in particulate matter (PM) and NOx levels. Additionally, some particles are products of photochemical reactions and will be higher at higher temperatures at any given precursor emission level.

Subgroups of the population that are most vulnerable to the effects of air pollution or heat are relatively well established [16,17]. They include the elderly; those in institutions, such as residential care homes, who are at particular risk; young children and asthma sufferers; people suffering from chronic diseases, particularly cardiovascular and respiratory conditions, renal diseases, diabetes, and obesity as well as those taking certain medications; people of lower socioeconomic status; and those living in densely populated urban neighborhoods [10].

To better assess the potential impact of current climate change scenarios on human health, it is necessary to understand not only the independent effects of temperature and other meteorological variables (adjusting for confounders, including pollutants) but also to elucidate any synergistic effects between meteorology and air pollution. It is reasonable to hypothesize that any such effects will become more important under extreme conditions that could occur in the future due to greater climate instability.

We report here the study of the potential synergy between air pollution and meteorology, including extreme weather events and their impact on mortality outcomes. These were undertaken within the framework of the PHASE Project (Public Health Adaptation Strategies to Extreme weather events), a European collaboration funded by the European Agency for Health and Consumers (EAHC) within the EU Commission Health Program 2008-2013. 


\section{Data and Methods}

In the PHASE project, a large data base including daily values of exposure and health outcome variables was compiled from nine cities spanning across Europe-Athens, Barcelona, Budapest, Helsinki, London, Paris, Rome, Stockholm, and Valencia-within the years 2004-2010. The data included mortality by cause and age group and meteorological and air pollution daily series.

The mortality data consisted of the daily number of deaths from all natural (ICD-9: 1-799; ICD-10: group A-R), cardiovascular (ICD-9: 390-459; ICD-10: group I), and respiratory causes (ICD-9: 460-519; ICD-10: group J) by specific age groups (15-64, 65-74, and $>75$ years and all ages). Mortality data were obtained from the official registries of each participating city.

The air pollution data included daily concentrations of gaseous and particulate pollutants, specifically, particulate matter with aerodynamic diameter $<10 \mu \mathrm{m}\left(\mathrm{PM}_{10}, 24-\mathrm{h}\right.$ mean), ozone $\left(\mathrm{O}_{3}\right.$, maximum 8 -h moving average $)$ and nitrogen dioxide $\left(\mathrm{NO}_{2}\right.$, mean 24 -h). The air pollution series were obtained from the urban monitoring network of each city.

The meteorological data consisted of daily series of air temperature $\left(1-\mathrm{h},{ }^{\circ} \mathrm{C}\right)$, dew point temperature $\left(1-\mathrm{h},{ }^{\circ} \mathrm{C}\right)$, relative humidity $(\%)$, wind speed $(\mathrm{m} / \mathrm{s})$ and direction (degrees), and sea level pressure (hPa). The main meteorological exposure variable used was apparent temperature (AT), which is a combination of hourly air temperature (temp) and dew point temperature (dew) using the following formula:

$$
\mathrm{AT}=-2.653+0.994 \times \text { temp }+0.0153 \times(\mathrm{dew})^{2}
$$

More details about the data and the calculation of AT may be found in De Donato et al. [18] and Kalkstein and Valimont [19].

\section{Statistical Analysis}

The analysis was carried out separately for the warm (April to September) and cold (October to March) periods from the years 2004 to 2010 as well as for each outcome and age group. Based on previous results $[3,20]$, the temperature and AT-mortality association was considered J-shaped in the warm season and linear in the cold season. Furthermore, a priori lags for the effects of AT were chosen. As it is known that heat effects are more immediate, lags $0-3$ days were considered for the warm season and for effects of heat waves. Cold-related effects on mortality are more prolonged and have been estimated to last about two weeks [3]. However, as the focus of the present paper is on temperature and pollution interaction, lags 0-6 days were considered for cold period because the effects of pollution are mostly observed at smaller lags. AT max was introduced as exposure variable for the warm period and AT min for the cold period.

The synergy between heat waves and air pollutants was studied for the summer months (June to August). We used the definition of a heat wave developed within the EUROHEAT project [4]. Briefly, heat waves were defined as (1) periods of at least two days with AT exceeding the 90th percentile of the monthly distribution of the particular city or (2) periods of at least two days in which the minimum temperature exceeded the 90th percentile of its respective distribution and AT exceeded the median monthly value. This definition for heat waves, which is described in detail in D' Ippoliti et al. [4], is based on extensive multi-city analysis and takes into account duration of high temperatures, geographical location, the time of the year, and the importance of both minimum and maximum temperatures.

A two stage statistical analysis plan was followed. For the first stage, i.e., the city-specific analysis, a Generalized Estimating Equations (GEE) modeling approach was applied [21]. We assumed a Poisson distribution for the outcome variable (daily number of deaths). Furthermore, we assumed that the observations within each season of a specific year are correlated while observations in different years are independent. Based on previous studies [2,3], a first order correlation structure was specified.

The equations of the model for (a) warm season, (b) cold season, and (c) heat waves are the following: 
(a)

$$
\log \mathrm{E}[\mathrm{Y}]=\mathrm{AT}_{+}+\mathrm{Pol}+\mathrm{AT}_{+} \times \mathrm{Pol}+\mathrm{AT}_{-}+[\text {covariates }]
$$

(b)

$$
\log \mathrm{E}[\mathrm{Y}]=\mathrm{AT}+\mathrm{Pol}+\mathrm{AT} \times \mathrm{Pol}+[\text { covariates }]
$$

(c)

$$
\log \mathrm{E}[\mathrm{Y}]=\mathrm{HW}+\mathrm{Pol}+\mathrm{HW} \times \mathrm{Pol}+[\text { covariates }]
$$

where $\mathrm{Y}$ is the number of deaths on each day with expectation $\mathrm{E}[\mathrm{Y}]$.

In the models on synergies of AT and heat waves, AT was entered in the model as a piecewise-linear term with different slopes above $\left(\mathrm{AT}_{+}\right)$and under $\left(\mathrm{AT}_{-}\right)$the turning point in the warm period analysis and as a linear term (AT) in the cold one. A dummy variable indicating a heat wave (HW) day was the main exposure variable when heat episodes were studied. Potential confounders introduced as covariates were air pollutants $\left(\mu \mathrm{g} / \mathrm{m}^{3}\right.$, lag $\left.0-1\right)$, barometric pressure (linear term, $\mathrm{hPa}$ ), wind speed (linear term, $\mathrm{m} / \mathrm{s}$ ), calendar month (five dummy variables), day of the week (six dummy variables), holiday (yes/no), and time trend (linear and quadratic term). The air pollutants were considered alternatively in each model. Separate analyses were done for each age group. For the investigation of interaction between temperature/heat wave and pollutant effects, an interaction term between temperature/heat wave and each pollutant separately was introduced in the model. To illustrate the results, the effect of a degree Celsius change in AT was estimated on a "high" and a "low" pollution day. As effect on a "low" pollution day, we presented the combined effects from each city on days with concentration of the pollutant equal to the 25th percentile of the city-specific pollutant distribution; as effect on a "high" pollutant day, we presented the corresponding effect calculated on days with concentrations equal to the 75th percentile of the same distribution. Similarly, the effect of heat wave days was estimated on a "high" and a "low" pollution day, as defined above. At the second stage of analysis, a quantitative summary of all individual-city results (interaction coefficient and effects of AT and heat waves on "low" and "high" pollution) was obtained using random effects meta-analysis according to the DerSimonian and Laird method [22].

As sensitivity analysis, we used the daily temperature and relative humidity measurements instead of AT. We applied the same models in terms of other covariates and lags but instead of AT, we used maximum daily temperature for the warm season and minimum daily temperature for the cold season and relative humidity in all models.

\section{Results}

In Tables 1 and 2, descriptive characteristics of the outcome and exposure variables in the participating cities are shown. The average total daily number of deaths ranged from 17 in Valencia to 133 in London, mainly reflecting the difference in the city populations. Air pollution and temperature indicators showed a large variability in the air quality and meteorological conditions among cities.

In Table 3, the synergistic effects between maximum $\mathrm{AT}$ and $\mathrm{O}_{3}, \mathrm{PM}_{10}$, and $\mathrm{NO}_{2}$ are shown for the warm season and for the three outcome variables i.e., all, cardiovascular (CVD), and respiratory number of deaths by age group. In general, the percentage increase in all deaths from natural causes per ${ }^{\circ} \mathrm{C}$ increase in AT tended to be greater during high ozone days, although this was only significant for all ages when all causes were considered. Specifically, on low ozone, days the increase in the total daily number of deaths was $1.84 \%(95 \%$ CI $0.87,2.82)$, whilst it is $2.20 \%(95 \%$ CI $1.28,3.13)$ in the high ozone days per $1{ }^{\circ} \mathrm{C}$ increase in AT. Interaction with $\mathrm{PM}_{10}$ was significant for CVD causes of death for all ages and for ages 75+. The increase in the CVD number of deaths for all ages associated with an increase of $1{ }^{\circ} \mathrm{C}$ in max AT during days with low $\mathrm{PM}_{10}$ was $2.24 \%$ (95\% CI 1.01, 3.47), whilst it was $2.63 \%\left(95 \%\right.$ CI 1.57, 3.71) during days with high $\mathrm{PM}_{10}$ levels. Significant interaction of $\mathrm{AT}$ and $\mathrm{PM}_{10}$ levels was also found when persons aged $75+$ were considered. No evidence for interaction between AT and $\mathrm{NO}_{2}$ was found. 
Table 1. Daily number of deaths by cause and age group in the participating cities.

\begin{tabular}{|c|c|c|c|c|c|c|c|c|}
\hline \multirow[t]{2}{*}{ City } & \multicolumn{4}{|c|}{$\begin{array}{c}\text { Daily Number of Deaths from All Natural Causes for All } \\
\text { Ages and by Age Group (Mean, sd) }\end{array}$} & \multicolumn{2}{|c|}{$\begin{array}{l}\text { Daily Number of Deaths } \\
\text { from Cardiovascular Causes } \\
\text { for All Ages and for Those } \\
>75 \text { Years Old (Mean, sd) }\end{array}$} & \multicolumn{2}{|c|}{$\begin{array}{l}\text { Daily Number of Deaths } \\
\text { from Respiratory Causes for } \\
\text { All Ages and for Those } \\
\text { >75 Years Old (Mean, sd) }\end{array}$} \\
\hline & All Ages & 15-64 Years & 65-74 Years & $>75$ Years & All Ages & $>75$ Years & All Ages & $>75$ Years \\
\hline Athens & $79.6(12.4)$ & $12.1(3.7)$ & $13.7(4.1)$ & $53.4(9.9)$ & $36.7(7.9)$ & $27.1(6.5)$ & $8.4(3.4)$ & $6.6(3.0)$ \\
\hline Barcelona & $37.8(8.5)$ & $4.9(2.3)$ & $5.6(2.5)$ & $27.3(7.0)$ & $12.0(4.2)$ & $9.8(3.7)$ & $4.3(2.7)$ & $4.2(2.9)$ \\
\hline Budapest & $64.2(10.1)$ & $14.5(4.0)$ & $13.2(3.7)$ & $34.4(7.0)$ & $30.9(6.9)$ & $21.5(5.5)$ & $3.0(1.9)$ & $1.6(1.3)$ \\
\hline Helsinki & $17.8(4.5)$ & $4.0(2.0)$ & $3.1(1.8)$ & $10.6(3.5)$ & $7.1(2.7)$ & $4.9(2.2)$ & $1.0(1.0)$ & $0.6(0.8)$ \\
\hline London & $132.9(19.5)$ & $23.8(5.2)$ & $22.7(5.4)$ & $85.5(14.9)$ & $47.0(9.7)$ & $33.1(7.5)$ & $19.5(7.0)$ & $15.1(5.8)$ \\
\hline Paris & $103.4(14.1)$ & $23.3(4.9)$ & $15.2(4.1)$ & $63.5(11.0)$ & $26.3(5.9)$ & $20.2(5.2)$ & $6.5(3.1)$ & $5.1(2.7)$ \\
\hline Rome & $58.0(10.0)$ & $7.5(2.8)$ & $10.3(3.4)$ & $39.9(8.1)$ & $23.5(5.9)$ & $18.9(5.2)$ & $3.6(2.1)$ & $3.0(1.9)$ \\
\hline Stockholm & $25.4(5.4)$ & $3.2(1.8)$ & $3.4(1.9)$ & $18.6(4.5)$ & $10.4(3.4)$ & $8.7(3.0)$ & $1.8(1.4)$ & $1.4(1.2)$ \\
\hline Valencia & $16.8(4.8)$ & $2.7(1.7)$ & $2.8(1.7)$ & $11.2(3.8)$ & $5.5(2.6)$ & $4.2(2.2)$ & $2.0(1.6)$ & $1.7(1.4)$ \\
\hline
\end{tabular}

Table 2. Descriptive characteristics of maximum apparent temperature (AT) and pollutant variables in each participating city.

\begin{tabular}{|c|c|c|c|c|}
\hline City & $\begin{array}{l}\operatorname{AT}\left(\operatorname{Max},{ }^{\circ} \mathrm{C}\right) \\
\text { Mean }(\mathrm{IQR} *)\end{array}$ & $\begin{array}{l}\mathrm{O}_{3}\left(\mu \mathrm{gm}^{-3}\right) \\
\text { Mean (IQR) }\end{array}$ & $\begin{array}{c}\operatorname{PM}_{10}\left(\mu \mathrm{gm}^{-3}\right) \\
\text { Mean (IQR) }\end{array}$ & $\begin{array}{c}\mathrm{NO}_{2}\left(\mu \mathrm{gm}^{-3}\right) \\
\text { Mean (IQR) }\end{array}$ \\
\hline \multicolumn{5}{|l|}{ Warm Season } \\
\hline Athens & $30.0(24.6,35.4)$ & $87.5(75.1,100.9)$ & $38.6(27.7,44.0)$ & $62.5(48.7,73.7)$ \\
\hline Barcelona & $25.5(20.8,30.7)$ & $55.2(43.0,65.0)$ & $37.5(26.0,45.8)$ & $32.8(22.0,42.0)$ \\
\hline Budapest & $22.3(17.7,27.0)$ & - & $30.7(21.6,37.9)$ & $34.7(25.4,42.7)$ \\
\hline Helsinki & $15.3(10.6,20.1)$ & $73.5(60.3,84.2)$ & $16.3(10.0,19.5)$ & $23.7(16.6,29.3)$ \\
\hline London & $18.4(15.0,21.6)$ & $48.6(35.4,60.3)$ & $21.4(14.8,26.4)$ & $36.4(27.2,44.1)$ \\
\hline Paris & $20.5(16.6,24.2)$ & $80.2(63.3,93.4)$ & $23.0(16.0,27.5)$ & $29.9(21.2,36.8)$ \\
\hline Rome & $26.4(20.9,31.5)$ & $98.3(84.2,111.3)$ & $32.0(25.2,37.3)$ & $52.0(41.2,61.9)$ \\
\hline Stockholm & $15.9(11.6,20.2)$ & $75.2(62.9,85.6)$ & $16.2(10.2,19.0)$ & $30.1(23.1,36.7)$ \\
\hline Valencia & $29.4(24.9,34.5)$ & $61.6(55.1,67.2)$ & $55.0(43.9,64.1)^{* *}$ & $49.0(38.0,58.5)$ \\
\hline \multicolumn{5}{|l|}{ Cold Season } \\
\hline Athens & $9.3(5.5,12.7)$ & $46.5(32.8,58.6)$ & $36.6(23.1,44.2)$ & $60.0(48.4,70.4)$ \\
\hline Barcelona & $6.6(2.5,9.3)$ & $24.8(13.0,34.4)$ & $39.3(26.0,49.0)$ & $47.1(35.0,57.0)$ \\
\hline Budapest & $-0.8(-4.4,2.5)$ & - & $41.8(25.9,54.6)$ & $42.7(32.0,51.0)$ \\
\hline Helsinki & $-5.1(-9.4,-1.7)$ & $51.2(40.6,61.9)$ & $14.4(8.8,17.4)$ & $27.5(18.5,33.5)$ \\
\hline London & $2.4(-1.2,5.6)$ & $24.0(8.5,36.8)$ & $23.7(16.5,28.1)$ & $48.2(36.6,57.6)$ \\
\hline Paris & $2.9(-0.7,6.0)$ & $37.7(21.4,51.8)$ & $25.2(16.0,30.4)$ & $44.1(34.1,52.7)$ \\
\hline Rome & $4.8(0.5,8.3)$ & $43.2(22.8,60.4)$ & $39.1(26.0,49.3)$ & $66.7(56.9,76.2)$ \\
\hline Stockholm & $-3.3(-6.8,-0.1)$ & $53.9(43.7,64.4)$ & $13.6(8.2,16.1)$ & $31.5(23.2,38.6)$ \\
\hline Valencia & $6.1(1.9,9.8)$ & $36.5(27.0,45.2)$ & $55.8(40.3,65.5)^{* *}$ & $63.5(51.2,74.7)$ \\
\hline
\end{tabular}

* IQR: interquartile range of the city specific distribution (25th, 75th percentile); ${ }^{* *}$ based on measurements for total suspended particles (TSP).

In Table 4, the synergistic effects between heat wave days and $\mathrm{O}_{3}, \mathrm{PM}_{10}$, and $\mathrm{NO}_{2}$ are shown. No consistent pattern was observed, and no consistent evidence for interaction was found.

In Table 5, the synergistic effects between minimum $\mathrm{AT}$ and $\mathrm{O}_{3}, \mathrm{PM}_{10}$, and $\mathrm{NO}_{2}$ in the cold season are shown. No evidence for synergy was found for any of the pollutants and health endpoints analyzed, with the exception of $\mathrm{NO}_{2}$ and all natural causes mortality for all ages, where there was a statistically significant interaction and the percentage increase in the daily number of deaths associated with a decrease in minimum apparent temperature by $1{ }^{\circ} \mathrm{C}$ was $0.76(95 \% \mathrm{CI} 0.60,0.93)$ on a day with low $\mathrm{NO}_{2}$ and $0.88 \%(95 \% \mathrm{CI} 0.68,1.08)$ on a day with high $\mathrm{NO}_{2}$.

We also analyzed the data from Mediterranean and North Central cities separately, and the results were consistent with the above patterns (Supplementary Material Figures S1 and S2).

From the sensitivity analysis results, using temperature and relative humidity separately in the models, we found that there were generally larger effects of temperature per ${ }^{\circ} \mathrm{C}$ compared to AT effects. The interaction of temperature with ozone levels for all causes of death for all ages was 
statistically significant with the increase in the daily number of deaths associated with $1{ }^{\circ} \mathrm{C}$ increase in max daily temperature equal to $2.64 \%(95 \%$ CI $0.89,4.43)$ in low ozone days and $2.86 \%(1.16,4.59)$ in high ozone days. The interactions observed between temperature and $\mathrm{PM}_{10}$ for all ages and among those $>75$ years for CVD deaths were on the same direction but did not reach the nominal level of statistical significance. Similarly, in the cold season, the interaction between temperature and $\mathrm{NO}_{2}$ was not statistically significant but followed the same pattern (Supplementary Material Table S1).

Table 3. Pooled (from nine city-specific estimates) percentage increase $(95 \% \mathrm{CI})$ in the daily number of deaths per degree Celsius increase in apparent temperature in the warm period in days with "low" (at the 25th percentile of each city-specific distribution) or "high" (at the corresponding 75th percentile) level of pollutant. Results from random effects meta-analysis.

\begin{tabular}{|c|c|c|c|c|c|c|}
\hline \multirow[b]{2}{*}{ Age Group } & \multicolumn{6}{|c|}{$\begin{array}{l}\% \text { Increase }(95 \% \mathrm{CI}) \text { in the Daily Number of Deaths from All Natural Causes Associated with } 1{ }^{\circ} \mathrm{C} \text { Increase } \\
\text { in Apparent Temperature on Days with: }\end{array}$} \\
\hline & Low $\mathrm{O}_{3}$ & High $\mathrm{O}_{3}$ & Low $\mathbf{P M}_{10}$ & High $\mathbf{P M}_{10}$ & Low $\mathrm{NO}_{2}$ & High $\mathrm{NO}_{2}$ \\
\hline $15-64$ years & $0.13(-0.37,0.64)$ & $0.33(-0.30,0.97)$ & $0.34(-0.60,1.29)$ & $0.51(-0.34,1.36)$ & $0.53(-0.21,1.29)$ & $0.89(0.00,1.78)$ \\
\hline $65-74$ years & $1.12(0.13,2.11)$ & $1.41(0.48,2.36)$ & $2.02(0.88,3.18)$ & $1.73(1.02,2.45)$ & $2.20(1.09,3.33)$ & $1.55(0.93,2.16)$ \\
\hline $75+$ years & $2.18(1.04,3.34)$ & $2.65(1.56,3.76)$ & $2.54(1.48,3.62)$ & $2.77(1.87,3.67)$ & $3.01(1.83,4.20)$ & $2.58(1.70,3.47)$ \\
\hline \multirow[t]{2}{*}{ All ages } & $1.84(0.87,2.82)$ & $2.20(1.28,3.13)$ & $2.26(1.33,3.21)$ & $2.30(1.56,3.05)$ & $2.51(1.51,3.53)$ & $2.16(1.43,2.90)$ \\
\hline & \multicolumn{6}{|c|}{$\begin{array}{l}\% \text { Increase }(95 \% \mathrm{CI}) \text { in the Daily Number of Deaths from Cardiovascular Causes Associated with } 1{ }^{\circ} \mathrm{C} \text { Increase } \\
\text { in Apparent Temperature on Days with: }\end{array}$} \\
\hline Age Group & Low $\mathrm{O}_{3}$ & $\mathrm{High}_{3}$ & Low $\mathbf{P M}_{10}$ & High $\mathrm{PM}_{10}$ & Low $\mathrm{NO}_{2}$ & High $\mathrm{NO}_{2}$ \\
\hline $15-64$ years & $0.48(-0.60,1.57)$ & $0.90(-0.43,2.26)$ & $0.70(-0.43,1.83)$ & $1.34(0.28,2.42)$ & $0.73(-0.32,1.80)$ & $1.83(0.52,3.14)$ \\
\hline $65-74$ years & $1.54(0.26,2.84)$ & $1.32(-0.24,2.90)$ & $2.46(0.64,4.32)$ & $1.88(0.43,3.35)$ & $2.66(0.95,4.39)$ & $1.73(0.12,3.37)$ \\
\hline $75+$ years & $2.35(1.00,3.71)$ & $2.66(1.45,3.88)$ & $2.26(0.99,3.53)$ & $2.85(1.73,3.98)$ & $3.11(1.72,4.53)$ & $2.68(1.59,3.79)$ \\
\hline \multirow[t]{2}{*}{ All ages } & $2.23(1.00,3.47)$ & $2.40(1.23,3.59)$ & $2.24(1.01,3.47)$ & $2.63(1.57,3.71)$ & $2.86(1.53,4.20)$ & $2.49(1.44,3.54)$ \\
\hline & \multicolumn{6}{|c|}{$\begin{array}{l}\text { \% Increase }\left(95 \% \text { CI) in the Daily Number of Deaths from Respiratory Causes Associated with } 1{ }^{\circ} \mathrm{C} \text { Increase }\right. \\
\text { in Apparent Temperature on Days with: }\end{array}$} \\
\hline Age Group & Low $\mathrm{O}_{3}$ & High $\mathrm{O}_{3}$ & Low $\mathbf{P M}_{10}$ & High $\mathrm{PM}_{10}$ & Low $\mathrm{NO}_{2}$ & High $\mathrm{NO}_{2}$ \\
\hline $15-64$ years & $1.94(-1.38,5.38)$ & $1.63(-0.35,3.65)$ & $1.39(-1.36,4.22)$ & $1.24(-0.71,3.23)$ & $2.38(0.35,4.45)$ & $1.68(-0.08,3.47)$ \\
\hline $65-74$ years & $3.29(-1.38,8.19)$ & $1.96(-1.13,5.14)$ & $2.67(-0.13,5.56)$ & $3.19(0.38,6.07)$ & $3.29(0.36,6.31)$ & $3.78(0.66,7.00)$ \\
\hline $75+$ years & $2.55(0.95,4.18)$ & $3.36(1.68,5.07)$ & $3.90(2.02,5.82)$ & $3.59(2.20,4.99)$ & $3.98(2.14,5.85)$ & $3.23(1.81,4.67)$ \\
\hline All ages & $2.84(0.98,4.74)$ & $3.40(1.70,5.13)$ & $4.32(2.19,6.49)$ & $3.76(2.20,5.34)$ & $4.13(2.06,6.24)$ & $3.43(1.98,4.91)$ \\
\hline
\end{tabular}

Note: in bold where the interaction term is statistically significant at the 0.05 level.

Table 4. Pooled (from nine city-specific estimates) percentage increase ( $95 \% \mathrm{CI}$ ) in the daily number of deaths in days with a heat wave and with "low" (at the 25th percentile of each city-specific distribution) or "high" (at the corresponding 75th percentile) level of pollutant. Results from random effects meta-analysis.

\begin{tabular}{|c|c|c|c|c|c|c|}
\hline \multirow[b]{2}{*}{ Age Group } & \multicolumn{6}{|c|}{ \% Increase $(95 \%$ CI) in the Daily Number of Deaths from All Natural Causes on Days with Heat-Waves and: } \\
\hline & Low $\mathrm{O}_{3}$ & High $\mathrm{O}_{3}$ & Low $\mathrm{PM}_{10}$ & High $\mathrm{PM}_{10}$ & Low $\mathrm{NO}_{2}$ & High $\mathrm{NO}_{2}$ \\
\hline $15-64$ years & $7.06(0.66,13.87)$ & $4.96(-0.70,10.94)$ & $2.86(-3.52,9.67)$ & $4.34(-1.19,10.18)$ & $4.67(-0.51,10.12)$ & $7.81(2.24,13.68)$ \\
\hline $65-74$ years & $3.23(-2.78,9.61)$ & $5.29(1.08,9.68)$ & $4.69(-1.41,11.16)$ & $6.86(2.80,11.08)$ & $6.21(1.08,11.60)$ & $8.33(2.52,14.46)$ \\
\hline $75+$ years & $10.74(3.70,18.26)$ & $10.66(7.01,14.43)$ & $10.25(5.94,14.72)$ & $11.19(7.62,14.88)$ & $14.03(9.69,18.53)$ & $13.41(8.52,18.52)$ \\
\hline \multirow[t]{2}{*}{ All ages } & $8.96(2.90,15.37)$ & $8.72(6.02,11.48)$ & $7.97(5.05,10.97)$ & $9.18(6.10,12.36)$ & $10.40(6.51,14.43)$ & $11.37(7.07,15.85)$ \\
\hline & \multicolumn{6}{|c|}{ \% Increase $(95 \% \mathrm{CI})$ in the Daily Number of Deaths from Cardiovascular Causes on Days with Heat-Waves and: } \\
\hline Age Group & Low $\mathrm{O}_{3}$ & $\mathrm{High}_{3}$ & Low $\mathrm{PM}_{10}$ & High $\mathrm{PM}_{10}$ & Low $\mathrm{NO}_{2}$ & High $\mathrm{NO}_{2}$ \\
\hline $15-64$ years & $7.51(-4.75,21.35)$ & $6.96(-4.39,19.66)$ & $-5.13(-21.00,13.92)$ & $1.60(-9.85,14.51)$ & $-2.61(-14.83,11.36)$ & $8.73(-2.05,20.70)$ \\
\hline $65-74$ years & $10.58(-0.58,22.99)$ & $5.09(-2.20,12.91)$ & $7.74(-4.84,21.99)$ & $6.54(-2.84,16.82)$ & $10.05(-0.83,22.12)$ & $6.69(-4.66,19.40)$ \\
\hline $75+$ years & $13.60(3.92,24.18)$ & $11.24(5.60,17.18)$ & $9.55(2.65,16.91)$ & $10.93(5.45,16.70)$ & $13.95(6.60,21.82)$ & $13.37(6.45,20.74)$ \\
\hline \multirow[t]{2}{*}{ All ages } & $12.33(3.67,21.71)$ & $9.18(4.31,14.27)$ & $7.51(1.76,13.59)$ & $8.69(3.28,14.38)$ & $10.80(4.34,17.66)$ & $11.55(4.78,18.75)$ \\
\hline & \multicolumn{6}{|c|}{ \% Increase $(95 \%$ CI) in the Daily Number of Deaths from Respiratory Causes on Days with Heat-Waves and: } \\
\hline Age Group & Low $\mathrm{O}_{3}$ & High $\mathrm{O}_{3}$ & Low $\mathrm{PM}_{10}$ & High $\mathrm{PM}_{10}$ & Low $\mathrm{NO}_{2}$ & High $\mathrm{NO}_{2}$ \\
\hline $15-64$ years & $51.58(-13.06,164.28)$ & $4.44(-17.11,31.59)$ & $1.80(-29.18,46.33)$ & $-0.76(-19.04,21.64)$ & $8.68(-15.17,39.23)$ & $7.39(-9.62,27.60)$ \\
\hline $65-74$ years & $2.30(-17.32,26.56)$ & $15.29(-6.60,42.31)$ & $11.66(-10.87,39.90)$ & $23.77(2.05,50.11)$ & $22.30(0.07,49.48)$ & $24.61(3.61,49.86)$ \\
\hline $75+$ years & $15.93(6.23,26.51)$ & $17.90(11.12,25.09)$ & $16.10(5.77,27.44)$ & $15.22(6.95,24.13)$ & $19.40(10.43,29.09)$ & $18.61(9.43,28.55)$ \\
\hline All ages & $13.58(4.97,22.90)$ & $16.99(10.82,23.51)$ & $13.90(4.40,24.26)$ & $18.18(9.16,27.94)$ & $21.10(12.02,30.93)$ & $20.43(12.63,28.76)$ \\
\hline
\end{tabular}

Note: in bold where the interaction term is statistically significant at the 0.05 level. 
Table 5. Pooled (from nine city-specific estimates) percentage increase ( $95 \% \mathrm{CI}$ ) in the daily number of deaths per degree Celsius decrease in apparent temperature in the cold period in days with "low" (at the 25th percentile of each city-specific distribution) or "high" (at the corresponding 75th percentile) level of pollutant. Results from random effects meta-analysis.

\begin{tabular}{|c|c|c|c|c|c|c|}
\hline \multirow[b]{2}{*}{ Age Group } & \multicolumn{6}{|c|}{$\begin{array}{l}\text { \% Increase }\left(95 \% \text { CI) in the Daily Number of Deaths from All Natural Causes Associated with } 1{ }^{\circ} \mathrm{C} \text { Decrease }\right. \\
\text { in Apparent Temperature on Days with: }\end{array}$} \\
\hline & Low $\mathrm{O}_{3}$ & High $\mathrm{O}_{3}$ & Low $\mathbf{P M}_{10}$ & High $\mathrm{PM}_{10}$ & Low $\mathrm{NO}_{2}$ & High $\mathrm{NO}_{2}$ \\
\hline $15-64$ years & $0.60(0.21,0.99)$ & $0.46(0.16,0.75)$ & $0.40(0.16,0.65)$ & $0.52(0.30,0.75)$ & $0.46(0.17,0.75)$ & $0.64(0.35,0.93)$ \\
\hline $65-74$ years & $0.67(0.25,1.09)$ & $0.73(0.43,1.02)$ & $0.68(0.29,1.08)$ & $0.80(0.47,1.14)$ & $0.73(0.45,1.01)$ & $0.88(0.46,1.31)$ \\
\hline $75+$ years & $0.90(0.66,1.14)$ & $0.82(0.54,1.09)$ & $0.92(0.68,1.16)$ & $0.81(0.59,1.04)$ & $0.85(0.62,1.08)$ & $0.95(0.70,1.20)$ \\
\hline \multirow[t]{2}{*}{ All ages } & $0.79(0.60,0.99)$ & $0.75(0.55,0.95)$ & $0.80(0.60,1.00)$ & $0.76(0.58,0.94)$ & $0.76(0.60,0.93)$ & $0.88(0.68,1.08)$ \\
\hline & \multicolumn{6}{|c|}{$\begin{array}{l}\% \text { Increase }(95 \% \mathrm{CI}) \text { in the Daily Number of Deaths from Cardiovascular Causes Associated with } 1{ }^{\circ} \mathrm{C} \text { Decrease } \\
\text { in Apparent Temperature on Days with: }\end{array}$} \\
\hline Age Group & Low $\mathrm{O}_{3}$ & High $\mathrm{O}_{3}$ & Low $\mathrm{PM}_{10}$ & High $\mathrm{PM}_{10}$ & Low $\mathrm{NO}_{2}$ & High $\mathrm{NO}_{2}$ \\
\hline 15-64 years & $0.95(0.12,1.79)$ & $1.14(0.17,2.12)$ & $0.65(-0.02,1.32)$ & $0.76(0.21,1.31)$ & $0.68(-0.05,1.41)$ & $0.99(0.22,1.78)$ \\
\hline $65-74$ years & $1.32(0.75,1.90)$ & $1.52(1.01,2.04)$ & $1.17(0.72,1.62)$ & $1.43(0.96,1.90)$ & $1.32(0.88,1.76)$ & $1.40(0.97,1.82)$ \\
\hline $75+$ years & $1.14(0.87,1.41)$ & $1.07(0.83,1.31)$ & $1.11(0.75,1.47)$ & $0.98(0.70,1.27)$ & $1.03(0.74,1.33)$ & $1.14(0.82,1.45)$ \\
\hline \multirow[t]{2}{*}{ All ages } & $1.13(0.84,1.43)$ & $1.09(0.85,1.34)$ & $1.10(0.74,1.47)$ & $1.04(0.76,1.32)$ & $1.05(0.78,1.32)$ & $1.17(0.84,1.50)$ \\
\hline & \multicolumn{6}{|c|}{$\begin{array}{l}\% \text { Increase }(95 \% \mathrm{CI}) \text { in the Daily Number of Deaths from Respiratory Causes Associated with } 1{ }^{\circ} \mathrm{C} \text { Decrease } \\
\text { in Apparent Temperature on Days with: }\end{array}$} \\
\hline Age Group & Low $\mathrm{O}_{3}$ & High $\mathrm{O}_{3}$ & Low $\mathrm{PM}_{10}$ & High $\mathrm{PM}_{10}$ & Low $\mathrm{NO}_{2}$ & High $\mathrm{NO}_{2}$ \\
\hline 15-64 years & $0.67(-1.00,2.38)$ & $0.41(-1.55,2.42)$ & $0.99(-0.73,2.74)$ & $0.83(-0.47,2.16)$ & $0.66(-0.70,2.04)$ & $1.10(-0.50,2.72)$ \\
\hline $65-74$ years & $0.78(-0.25,1.82)$ & $0.96(-0.05,1.98)$ & $1.01(0.07,1.96)$ & $1.12(0.27,1.97)$ & $1.15(0.23,2.09)$ & $1.40(0.47,2.33)$ \\
\hline $75+$ years & $0.90(0.31,1.49)$ & $0.99(0.47,1.51)$ & $1.10(0.42,1.79)$ & $0.99(0.51,1.48)$ & $0.79(0.27,1.31)$ & $1.18(0.66,1.71)$ \\
\hline All ages & $0.68(0.05,1.31)$ & $0.78(0.08,1.48)$ & $1.00(0.37,1.63)$ & $0.91(0.43,1.39)$ & $0.80(0.34,1.26)$ & $1.10(0.53,1.67)$ \\
\hline
\end{tabular}

Note: in bold where the interaction term is statistically significant at the 0.05 level.

\section{Discussion}

The PHASE project was one of the first multi-city projects to examine potential synergistic effects on mortality between meteorology and air pollution. In the warm season, we found significant interaction between AT and temperature and ozone concentrations for their effects on the total daily number of deaths for all ages. The AT effects appeared to be larger for CVD causes on days with increased $\mathrm{PM}_{10}$ concentrations, although not to a statistically significant level in sensitivity analysis. No consistent evidence was found for interaction with air pollution when heat waves were considered. In the cold season, there was no consistent evidence for AT or temperature/air pollution interaction.

There have been few studies addressing the issue of synergy between meteorology and pollution and their effects on health. Among the reported studies, more have investigated hot weather rather than cold weather. Some studies have reported effects of temperature modified by pollutants and some have reported effects of pollutants modified by temperature. However, although the interaction was the same in statistical terms, the results reported did not always allow comparisons by magnitude of effects. The results found in the present analysis of effect modification by $\mathrm{PM}_{10}$ and a suggestion for ozone with respect to warm/hot temperatures are consistent with a number of reports in the literature. Thus, Sartor et al. [23] reported synergy with ozone; Parodi et al. [24] and Ren et al. [25] also reported synergy between temperature and ozone exposure for effects on cardiovascular mortality. In a study in Germany, Breitner et al. [26] reported effect modification in the temperature-mortality association by $\mathrm{O}_{3}$. Jhun et al. [27] examined the effect modification by temperature on the $\mathrm{O}_{3}$ effect; although they did not find a statistically significant interaction, they observed a pattern compatible with some effect modification. Several studies have reported synergy of temperature and PM for effects on total non-accidental deaths and on cardiovascular mortality [28-31]. In Hefei, China, a study found synergy between $\mathrm{PM}_{10}$ concentrations and temperature in their effects on mortality, which was more pronounced in females and in the illiterate [32]. However there have also been studies that have observed no synergy either with $\mathrm{PM}$ or $\mathrm{O}_{3}$ or both [1,26,33,34]. Part of the inconsistency in the reported results may be attributed to specific characteristics of the cities or areas where the studies were done. For example, population exposure to outdoor temperature and pollution may differ according to air condition use, design aspects of homes, local habits related to opening windows, etc. Another problem 
can be the fact that analysis methods followed were not consistent and did not allow comparisons. For example, some studies have mutually adjusted for air pollutants, while others used single pollutant models. However, there is accumulating evidence that the warm/hot increasing temperature effects are enhanced by high pollution levels (especially $\mathrm{PM}_{10}$ and ozone) and vice versa and that effects of pollutants are enhanced by the presence of high temperature.

Most of the studies conducted so far have examined effects on mortality. However, Lepeule et al. [35] examined the effects of temperature and its interaction with black carbon concentrations on lung function in an elderly cohort of men and found some indication of synergy. This may indicate that the synergistic effects between meteorological variables-most importantly temperature-and health effects, including outcomes other than mortality, deserve more attention. More research on this topic is needed to enhance our understanding of the ways in which these interconnected environmental exposures interact.

As described above, most studies have investigated temperature-mortality interaction and only a few studies have addressed heat waves directly. The lack of identifiable and consistent synergistic effects with heat waves and ozone/ $\mathrm{PM}_{10}$ in the present study is in contrast with previously reported results from the EuroHEAT project [36]. The analysis of Analitis et al. largely concerned the same cities but for an earlier period (1990 to 2004), which included the major heat wave that occurred in 2003. Another older study in Athens that reported synergistic effects [37] included a major heat wave that occurred in 1987. A reason for this discrepancy may be the fact that no such major heat wave was present after 2004. Additionally, the warmest cities in Europe have developed and implemented prevention plans and thus reduced the effects of heat waves [18]. Although the study of interaction with air pollution concentrations and the occurrence of a heat wave is very important, there is a lack of related results. The investigation is further hindered by the lack of consistent definition of what constitutes a heat wave as well as the limitation in statistical power because heat wave days are relatively rare.

Some studies have looked at the effects of temperature, including the cold season and low temperatures. Burkart et al. [38] produced bivariate response surfaces, including high and low temperatures, in a study in Berlin and Lisbon. They found evidence of interaction of air pollutants concentrations with high temperature on mortality effects but little evidence of interaction during the cold season. Cheng and Kan [39] reported a significant interaction of $\mathrm{PM}_{10}$ and $\mathrm{O}_{3}$ and cold temperature on mortality outcomes in Shanghai, China. A recent multi-city study in Europe researched eight cities of which five-Athens, Barcelona, Helsinki, Rome, and Stockholm-were overlapping with the present work. However, the study used different city-specific time periods and different analysis methods and emphasized ultrafine particles. The study found interactive effects between pollutants and hot temperatures but only reported an indication of an interaction between low temperature and ultrafines for the cold season [40].

Our study had the advantage of including a large database from diverse locations in Europe representing large climatic variability as well as variability in the air pollution levels and mix. However, our study also had several limitations. Firstly, our study shared the measurement error problems of all ecological studies that use a series of measurements done at fixed sites to represent the daily exposure of the whole population living in the same city. However, the consistency of findings based on the same methods worldwide indicates that there are effects on mortality from outdoor level temperature and air pollution, which may in fact be underestimated because of measurement error [6]. Thus, the investigation of synergy is valid and useful, although the results may be underestimated. Secondly, we did not have data on variables that may act as effect modifiers either characterizing housing conditions, such as the use of air conditioning, or changes in lifestyle as people become aware of the potential consequences of extreme weather conditions. 


\section{Conclusions}

In an analysis of data from 2004 to 2010 in nine European cities, we found some evidence of interactive effects between hot temperature and the levels of ozone and $\mathrm{PM}_{10}$ on daily deaths but no evidence of such synergy specifically during heat wave days. No consistent synergy could be identified during the cold season.

Supplementary Materials: The following are available online at http:/ /www.mdpi.com/1660-4601/15/9/1856/ s1, Figure S1: Pooled percent increase (95\% Confidence Intervals-CI) in the daily number of deaths by cause and age group, per degree Celsius increase in max apparent temperature in the warm period, in days with "low" (at the 25th percentile of each city-specific distribution) or "high" (at the corresponding 75th percentile) level of pollutant in the Mediterranean (Athens, Barcelona, Rome, Valencia) and North-central (Budapest, Helsinki, London, Paris, Stockholm) cities. Results from random effects meta-analysis, Figure S2: Pooled percent increase ( $95 \%$ Confidence Intervals-CI) in the daily number of deaths by cause and age group, per degree Celsius decrease in min apparent temperature in the cold period, in days with "low" (at the 25th percentile of each city-specific distribution) or "high" (at the corresponding 75th percentile) level of pollutant in the Mediterranean (Athens, Barcelona, Rome, Valencia) and North-central (Budapest, Helsinki, London, Paris, Stockholm) cities. Results from random effects meta-analysis, Table S1: Sensitivity analysis: Pooled (from 9 city-specific estimates) percent increase (95\% Confidence Intervals-CI) in the daily number of deaths per degree Celsius change in temperature in days with "low" (at the 25th percentile of each city-specific distribution) or "high" (at the corresponding 75th percentile) level of pollutant. Results from random effects meta-analysis (in bold where the interaction term is statistically significant at the 0.05 level).

Author Contributions: Conceptualization: P.M., K.K. and F.d.D.; Methodology and Analysis: A.A. and M.S.; Resources, data acquisition, and curation: A.A., F.d.D., T.L., X.B., F.B., C.A., A.P., M.P. and A.G.; Writing-original draft preparation: A.A. and K.K.; Writing—review, contributions, and editing: all authors; Supervision: K.K., F.d.D., and P.M.; Project administration: F.d.D.; Funding acquisition: P.M.

Funding: This research was co-funded by the European Union in the framework of the Health Programme, grant No. 20101103 (PHASE project) (Antonio Gasparrini was supported by grants from the Medical Research Council UK (Grant ID: MR/M022625/1) and the Natural Environment Research Council UK (Grant ID: NE/R009384/1).

Conflicts of Interest: The authors declare no conflict of interest.

\section{References}

1. Zanobetti, A.; Schwartz, J. Temperature and mortality in nine US cities. Epidemiology 2008, 19, 563-570. [CrossRef] [PubMed]

2. Baccini, M.; Biggeri, A.; Accetta, G.; Kosatsky, T.; Katsouyanni, K.; Analitis, A.; Anderson, H.R.; Bisanti, L.; D'Ippoliti, D.; Danova, J.; et al. Heat effects on mortality in 15 European cities. Epidemiology 2008, 19, 711-719. [CrossRef] [PubMed]

3. Analitis, A.; Katsouyanni, K.; Biggceri, A.; Bacini, M.; Forsberg, B.; Bisanti, L.; Kirchmayer, U.; Ballester, F.; Cadum, E.; Goodman, P.G.; et al. Effects of cold weather on mortality: Results from 15 European cities within the PHEWE project. Am. J. Epidemiol. 2008, 168, 1397-1408. [CrossRef] [PubMed]

4. D’Ippoliti, D.; Michelozzi, P.; Marino, C.; de'Donato, F.; Menne, B.; Katsouyanni, K.; Kirchmayer, U.; Analitis, A.; Medina-Ramón, M.; Paldy, A.; et al. The impact of heat waves on mortality in 9 European cities: Results from the EuroHEAT project. Environ Health 2010, 9, 37. [CrossRef] [PubMed]

5. Gasparrini, A.; Guo, Y.; Hashizume, M.; Lavigne, E.; Zanobetti, A.; Schwartz, J.; Tobias, A.; Tong, S.; Rocklöv, J.; Forsberg, B.; et al. Mortality risk attributable to high and low ambient temperature: A multicountry observational study. Lancet 2015, 386, 369-375. [CrossRef]

6. Guo, Y.; Gasparrini, A.; Armstrong, B.G.; Tawatsupa, B.; Tobias, A.; Lavigne, E.; Coelho, M.S.Z.S.; Pan, X.; Kim, H.; Hashizume, M.; et al. Heat Wave and Mortality: A. Multicountry, Multicommunity Study. Environ. Health Perspect. 2017, 125, 087006. [CrossRef] [PubMed]

7. Michelozzi, P.; de Donato, F.; Bisanti, L.; Russo, A.; Cadum, E.; DeMaria, M.; D’Ovidio, M.; Costa, G.; Perucci, C.A. The impact of the summer 2003 heat waves on mortality in four Italian cities. Euro Surveill. 2005, 10, 161-165. [CrossRef] [PubMed]

8. Le Tertre, A.; Lefranc, A.; Eilstein, D.; Declercq, C.; Medina, S.; Blanchard, M.; Chardon, B.; Fabre, P.; Filleul, L.; Jusot, J.F.; et al. Impact of the 2003 heatwave on all-cause mortality in 9 French cities. Epidemiology 2006, 17, 75-79. [CrossRef] [PubMed] 
9. WHO. Air Quality Guidelines. Global Update 2005. Particulate Matter, Ozone, Nitrogen Dioxide and Sulfur Dioxide; WHO: Geneva, Switzerland, 2005.

10. WHO. Review of Evidence on Health Aspects of Air Pollution-REVIHAAP Project; Final Technical Report; WHO: Geneva, Switzerland, 2013.

11. Atkinson, R.W.; Kang, S.; Anderson, H.R.; Mills, I.C.; Walton, H.A. Epidemiological time series studies of $\mathrm{PM}_{2.5}$ and daily mortality and hospital admissions: A systematic review and meta-analysis. Thorax 2014, 69, 660-665. [CrossRef] [PubMed]

12. Katsouyanni, K.; Touloumi, G.; Spix, C.; Schwartz, J.; Balducci, F.; Medina, S.; Rossi, G.; Wojtyniak, B.; Sunyer, J.; Bacharova, L.; et al. Short-term effects of ambient sulphur dioxide and particulate matter on mortality in 12 European cities: Results from time series data from the APHEA project. BMJ 1997, 314, 1658-1663. [CrossRef] [PubMed]

13. Samet, J.M.; Zeger, S.L.; Dominici, F.; Curriero, F.; Coursac, I.; Dockery, D.W.; Schwartz, J.; Zanobetti, A. The National Morbidity, Mortality, and Air Pollution Study. Part II: Morbidity and mortality from air pollution in the United States. Res. Rep. Health Eff. Inst. 2000, 94, 5-70. [PubMed]

14. Katsouyanni, K.; Samet, J.M.; Anderson, H.R.; Atkinson, R.; Le Tertre, A.; Medina, S.; Samoli, E.; Touloumi, G.; Burnett, R.T.; Krewski, D.; et al. Air pollution and health: A European and North American approach (APHENA). Res. Rep. Health Eff. Inst. 2009, 142, 5-90.

15. Ebi, K.L.; McGregor, G. Climate change, tropospheric ozone and particulate matter, and health impacts. Environ. Health Perspect. 2008, 116, 1449-1455. [CrossRef] [PubMed]

16. Katsouyanni, K.; Trichopoulos, D.; Zavitsanos, X.; Touloumi, G. The 1987 Athens heatwave. Lancet 1988, 2, 573. [CrossRef]

17. Lippmann, M.; Schlesinger, R.B. Toxicological bases for the setting of health-related air pollution standards. Ann. Rev. Public Health 2000, 21, 309-333. [CrossRef] [PubMed]

18. De' Donato, F.K.; Leone, M.; Scortichini, M.; De Sario, M.; Katsouyanni, K.; Lanki, T.; Basagaña, X.; Ballester, F.; Åström, C.; Paldy, A.; et al. Changes in the Effect of Heat on Mortality in the Last 20 Years in Nine European Cities. Results from the PHASE Project. Int. J. Environ. Res. Public Health 2015, 12, 15567-15583. [CrossRef] [PubMed]

19. Kalkstein, L.S.; Valimont, K.M. An evaluation of summer discomfort in the United States using a relative climatological index. Am. Meteorol. Soc. 1986, 67, 842-848. [CrossRef]

20. Curriero, F.C.; Heiner, K.S.; Samet, J.M.; Zeger, S.L.; Strug, L.; Patz, J.A. Temperature and mortality in 11 cities of the eastern United States. Am. J. Epidemiol. 2002, 155, 80-87. [CrossRef] [PubMed]

21. Liang, K.Y.; Zeger, S.L. Longitudinal analysis using generalized linear models. Biometrika 1986, 73, 13-22. [CrossRef]

22. DerSimonian, R.; Laird, N. Meta-analysis in clinical trials. Control. Clin. Trials 1986, 7, 177-188. [CrossRef]

23. Sartor, F.; Demuth, C.; Snacken, R.; Walckiers, D. Mortality in the elderly and ambient ozone concentration during the hot summer, 1994, in Belgium. Environ. Res. 1997, 72, 109-117. [CrossRef] [PubMed]

24. Parodi, S.; Vercelli, M.; Garrone, E.; Fontana, V.; Izzotti, A. Ozone air pollution and daily mortality in Genoa, Italy between 1993 and 1996. Public Health 2005, 119, 844-850. [CrossRef] [PubMed]

25. Ren, C.; Williams, G.M.; Morawska, L.; Mengersen, K.; Tong, S. Ozone modifies associations between temperature and cardiovascular mortality: Analysis of the NMMAPS data. Occup. Environ. Med. 2008, 65, 255-260. [CrossRef] [PubMed]

26. Breitner, S.; Wolf, K.; Devlin, R.B.; Diaz-Sanchez, D.; Peters, A.; Schneider, A. Short-term effects of air temperature on mortality and effect modification by air pollution in three cities of Bavaria, Germany: A time-series analysis. Sci. Total Environ. 2014, 485-486, 49-61. [CrossRef] [PubMed]

27. Jhun, I.; Fann, N.; Zanobetti, A.; Hubbell, B. Effect modification of ozone-related mortality risks by temperature in 97 US cities. Environ. Int. 2014, 73, 128-134. [CrossRef] [PubMed]

28. Roberts, S. Interactions between particulate air pollution and temperature in air pollution mortality time series studies. Environ. Res. 2004, 96, 328-337. [CrossRef] [PubMed]

29. Ren, C.; Williams, G.M.; Tong, S. Does particulate matter modify the association between temperature and cardiorespiratory diseases? Environ. Health Perspect. 2006, 114, 1690-1696. [CrossRef] [PubMed]

30. Qian, Z.; He, Q.; Lin, H.M.; Kong, L.; Bentley, C.M.; Liu, W.; Zhou, D. High temperatures enhanced acute mortality effects of ambient particle pollution in the "oven" city of Wuhan, China. Environ. Health Perspect. 2008, 116, 1172-1178. [CrossRef] [PubMed] 
31. Stafoggia, M.; Schwartz, J.; Forastiere, F.; Perucci, C.A.; SISTI Group. Does temperature modify the association between air pollution and mortality? A multicity case-crossover analysis in Italy. Am. J. Epidemiol. 2008, 167, 1476-1485. [CrossRef] [PubMed]

32. Qin, R.X.; Xiao, C.; Zhu, Y.; Li, J.; Yang, J.; Gu, S.; Xia, J.; Su, B.; Liu, Q.; Woodward, A. The interactive effects between high temperature and air pollution on mortality: A time-series analysis in Hefei, China. Sci. Total Environ. 2017, 575, 1530-1537. [CrossRef] [PubMed]

33. Hales, S.; Salmond, C.; Town, G.I.; Kjellstrom, T.; Woodward, A. Daily mortality in relation to weather and air pollution in Christchurch, New Zealand. Aust. N. Z. J. Public Health 2000, 24, 89-91. [CrossRef] [PubMed]

34. Basu, R.; Feng, W.Y.; Ostro, B.D. Characterizing temperature and mortality in nine California counties. Epidemiology 2008, 19, 138-145. [CrossRef] [PubMed]

35. Lepeule, J.; Litonjua, A.A.; Gasparrini, A.; Koutrakis, P.; Sparrow, D.; Vokonas, P.S.; Schwartz, J. Lung function association with outdoor temperature and relative humidity and its interaction with air pollution in the elderly. Environ. Res. 2018, 165, 110-117. [CrossRef] [PubMed]

36. Analitis, A.; Michelozzi, P.; D’Ippoliti, D.; De’Donato, F.; Menne, B.; Matthies, F.; Atkinson, R.W.; Iñiguez, C.; Basagaña, X.; Schneider, A.; et al. Effects of heat waves on mortality: Effect modification and confounding by air pollutants. Epidemiology 2014, 25, 15-22. [CrossRef] [PubMed]

37. Katsouyanni, K.; Pantazopoulou, A.; Touloumi, G.; Tselepidaki, I.; Moustris, K.; Asimakopoulos, D.; Poulopoulou, G.; Trichopoulos, D. Evidence for interaction between air pollution and high temperature in the causation of excess mortality. Arch. Environ. Health 1993, 48, 235-242. [CrossRef] [PubMed]

38. Burkart, K.; Canário, P.; Breitner, S.; Schneider, A.; Scherber, K.; Andrade, H.; Alcoforado, M.J.; Endlicher, W. Interactive short-term effects of equivalent temperature and air pollution on human mortality in Berlin and Lisbon. Environ. Pollut. 2013, 183, 54-63. [CrossRef] [PubMed]

39. Cheng, Y.; Kan, H. Effect of the interaction between outdoor air pollution and extreme temperature on daily mortality in Shanghai, China. J. Epidemiol. 2012, 22, 28-36. [CrossRef] [PubMed]

40. Chen, K.; Wolf, K.; Breitner, S.; Gasparrini, A.; Stafoggia, M.; Samoli, E.; Andersen, Z.J.; Bero-Bedada, G.; Bellander, T.; Hennig, F.; et al. Two-way effect modifications of air pollution and air temperature on total natural and cardiovascular mortality in eight European urban areas. Environ. Int. 2018, 116, 186-196. [CrossRef] [PubMed] 